\title{
Effect of lime treatment of olive meal on in vitro utilization of total mixed ration containing olive meal as partial maize replacer
}

\author{
Ajmal Ashraf, R. K. Sharma and Ankur Rastogi \\ Division of Animal Nutrition, Faculty of Veterinary Sciences and Animal Husbandry \\ Sher-e-Kashmir University of Agricultural sciences and Technology-Jammu, R. S. Pura -181102, India \\ Corresponding author: Ajmal Ashraf, email: ajmalashraf96@yahoo.com \\ Received: 05-11-2012, Accepted: 16-12-2012, Published online: 30-04-2013
}

\section{How to cite this article:}

Ashraf A, Sharma RK and Rastogi A (2013) Effect of lime treatment of olive meal on in vitro utilization of total mixed ration containing olive meal as partial maize replacer, Vet World 6(7): 440-443, doi: 10.5455/vetworld.2013.440-443

\begin{abstract}
Aim: Present study pertains to lime treatment of olive meal to improve its digestibility. The objective of the present study was to assess the in vitro dry matter degradability of total mixed ration containing lime treated olive meal at varied levels of maize replacement to know the optimum level of lime and treated olive meal as maize replacement in small ruminant diets.

Materials and methods: Study was carried out in two phases. In phase I, A complete diet was formulated and treated with lime at variable concentrations (0-8\%) at $25 \%$ of maize replacement and subjected to in vitro studies as per Tilley and Terry. On the basis of the results of this phase, a concentration of lime for olive treatment was selected and tested at variable levels of maize replacement $(0-50 \%)$ by treated olive cake in phase II. Data was analyzed as per the procedures suggested by Snedecor and Cochran.
\end{abstract}

Results: The in vitro dry matter digestibility (IVDMD) of composite diet increased from $43.95 \%$ at $0 \%$ lime treatment to $48.68 \%$ on treating with $8 \%$ lime with significant $(P<0.05)$ increase at $6 \%$ treatment level. Lime treatment beyond 6\% had no further significant effect on improving the digestibility. Graded levels of maize replacement by olive meal treated with $6 \%$ lime (lime percentage selected from phase I) showed that the in vitro digestibility of mixed ration was not compromised up to $40 \%$ replacement level of maize by treated olive meal. Improved digestibility with lime treatment may be due to weakening of internal Hydrogen bonding, thereby disrupting the fiber structure in olive meal. Further lime may be saponifying the high level of fat present in olive meal, which may otherwise negatively impact the digestibility values.

Conclusion: It can be concluded that the treatment with up to $6 \%$ of lime can effectively increase the digestibility of olive meal. Treated olive meal can replace up to $40 \%$ of maize from daily ration without affecting the digestibility of composite ration. Thus incorporating lime treated olive meal may prove beneficial to livestock producers.

Key words: In vitro dry matter digestibility, lime, maize replacement, olive meal

\section{Introduction}

Olive (Olea europaea) production is distributed over all the five continents. It is especially important in the Mediterranean area, Spain being first as regards total cultivable area and number of productive trees. Both olive tree culture and olive oil industry produce large amounts of by-products. Olive meal is a promising unconventional feed stuff [1], which is available at very cheap prices near olive oil extraction plants and has potential to partially replace maize from the ration of ruminants [2,3]. Olive oil industry produces large amounts of various byproducts. It has been estimated, that olive oil industry produces $25 \mathrm{~kg}$ of crude olive meal per $100 \mathrm{~kg}$ of raw olive fruit. About 400 hectares of land is under olive plantation in Jammu province, which produces about 9 metric tons of olive meal, which is available from olive oil extraction mills located at Doda and Ramban of Jammu province [2].

Olive meal is a promising unconventional feed stuff

This article is an open access article licensed under the terms of the Creative Commons Attribution License (http://creativecommons. org/licenses/by/2.0) which permits unrestricted use, distribution and reproduction in any medium, provided the work is properly cited.
[1]. It is a rough ligno-cellulosic feed characterized by high percentage of crude fibre (CF), particularly rich in lignin, low crude protein (CP) [4] but having a surprisingly high oil percentage [2]. Further, many workers have shown its poor digestive utilization in ruminants. This may be attributed to decrease in activity of the rumen microflora by 40 per cent after ingestion of crude olive meal [5]. A researcher [2] reported that crude olive meal can replace $25 \%$ of maize from goat's ration, without compromising the health, nutrient intake and body weight maintenance of adult male goats, however, when replacement levels higher than $25 \%$ were tested in vitro, significant decline in dry matter degradability was noted. Various theories have been advanced to explain the reason for poor digestibility. High fat content, its composition and ligno-cellulosic nature of olive meal have been suggested as the incriminating factors. A study [4] suggested that there is the same phenomenon of "protection" of carbohydrates related to lignin with olive meal as occurs with straw and when olive meal was treated with alkalis it's in vitro digestibility increased by almost four times. Keeping this background in view, 
Table-1. Ingredient composition (\%) of concentrate mixtures used as Experimental ration for in vitro studies.

\begin{tabular}{|c|c|c|c|c|c|c|c|}
\hline Ingredients & Control & $T_{1}$ & $\mathrm{~T}_{2}$ & $\mathrm{~T}_{3}$ & $\mathrm{~T}_{4}$ & $\mathrm{~T}_{5}$ & $\mathbf{T}_{6}$ \\
\hline Maize replaced by olive meal (\%) & 0 & 25 & 30 & 35 & 40 & 45 & 50 \\
\hline Maize & 30 & 22.5 & 21 & 19.5 & 18 & 16.5 & 15 \\
\hline Mustard oil cake & 37 & 37 & 37 & 37 & 37 & 37 & 37 \\
\hline Wheat Bran & 30 & 30 & 30 & 30 & 30 & 30 & 30 \\
\hline Olive meal & - & 9 & 9 & 10.5 & 12 & 13.5 & 15 \\
\hline Mineral Mixture & 2 & 2 & 2 & 2 & 2 & 2 & 2 \\
\hline Salt & 1 & 1 & 1 & 1 & 1 & 1 & 1 \\
\hline
\end{tabular}

it was hypothesized that treatment with lime $\left\{\mathrm{Ca}(\mathrm{OH})_{2}\right\}$ can help in addressing the factors that limit the utilization of olive meal. Chemical treatment with lime is aimed at weakening the ligno-cellulosic structure of olive meal to improve the accessibility of structural carbohydrates to cellulytic micro-organisms, as well as it can form calcium salts with the free fatty acids of olive, thereby alleviating their depressing action on digestibility and still maintaining their availability to the animal.

The aim of the present work was to evaluate the potential of adding lime treated olive meal as unconventional feed source in the ration of small ruminants.

\section{Materials and Methods}

The experiment was conducted at Faculty of Veterinary Sciences, Sher-e-Kashmir university of Agricultural Sciences, Jammu. The study involved scrutinizing effect of lime treatment of olive meal and variable levels of maize replacement by treated olive meal on the in vitro dry matter degradability of the composite diet. Olive meal meant for experimental trial was procured from an olive oil mill located at Ramban district of Jammu and Kashmir.

PHASE-I (Selection of effective level of lime treatment) Proximate analysis and fiber fractionation: Proximate analysis of olive meal was done as per [6] and fiber fractions [Neutral detergent fibre (NDF) and Acid detergent fiber (ADF)] were done as per the method of Van Soest [7].

Treatment of olive meal: Lime solutions of different concentrations $(0-8 \%)$ were prepared and sprinkled on the olive samples at the rate of $20 \mathrm{ml}$ solution per $100 \mathrm{gm}$ of olive meal. The samples were then placed in air tight polythene bags and left undisturbed for one week. After one week of incubation [8] samples were opened and used for in vitro dry matter digestibility (IVDMD) studies as per Tilley, J. M.A. and Terry, R.A. [9].

In vitro study: The in vitro study to assess the effect of inclusion of lime treated olive meal as maize replacer in the concentrate mixture of composite feed was carried out in two parts. First the effective level of lime for treatment of olive meal was selected and then in part II, effective percentage of olive meal that can potentially replace maize in the composite diet was fixed. In part I, the IVDMD of composite standard diet (without olive meal) was compared with treatment diets containing olive meal treated with lime at variable concentrations $(0-8 \%)$ at $25 \%$ of maize replacement as per [9]. On the basis of the result of this part, a concentration of lime for olive meal treatment was selected and tested at variable level of maize replacement $(0-50 \%)$ by treated olive meal in part II. Rumen liquor was collected with a stomach tube fitted with vacuum pump from local goats, 4-5 hours after morning feeding. Collected sample of rumen liquor was transferred into a preheated thermos flask, filtered through a four-layered muslin cloth and flushed with $\mathrm{CO}_{2}$ for 60 seconds. Incubation medium is prepared under continuous flushing of $\mathrm{CO}_{2}$. Ingredient composition of different concentrate mixtures formulated for in vitro study are detailed in Table-1.

Duplicate samples of $0.5 \mathrm{~g}$ ground composite feed (passed through $1.0 \mathrm{~mm}$ screen) were taken in Erlenmeyer flask. To it $40 \mathrm{ml}$ of incubation medium and $10 \mathrm{ml}$ of strained rumen liquor were added. $\mathrm{CO}_{2}$ gas was bubbled in the flask for 10 minutes. Flasks were closed with Bunsen valves and inlet tubes. The flasks were incubated for 24 hours in incubator at $39^{\circ} \mathrm{C}$. After incubation, the flasks were washed with $100 \mathrm{ml}$ neutral detergent solution in $500 \mathrm{ml}$ spout-less beaker to make total volume to $150 \mathrm{ml}$. The samples were refluxed for 1 $\mathrm{h}$ at $100^{\circ} \mathrm{C}$ and then filtered through pre-weighed Gooch crucibles (G2). The samples were washed repeatedly with hot water and finally with acetone to remove the detergent completely. The crucibles were dried at $100^{\circ} \mathrm{C}$ for $24 \mathrm{~h}$. and then weights were recorded. The in vitro analysis was repeated twice. In vitro dry matter digestibility (\%) was calculated using following formula;

Calculations: Weight of crucible $=\mathrm{W}(\mathrm{g})$; Weight of sample on dry matter basis $=\mathrm{W} 1(\mathrm{~g})$; Weight of residue + crucible $=\mathrm{W} 2(\mathrm{~g})$; Weight of residue left 'W3' $(\mathrm{g})=$ W2 - W; Net digestible dry matter $(\mathrm{g})=\mathrm{W} 1$ - W3 $\%$ IVDMD=Net digestible dry matter (g)/Weight of sample on DM basis (g) x 100

Phase II (selection of replacement level): On the basis of the result of phase I, a concentration of lime for olive meal treatment was selected and tested at variable level of maize replacement $(0-50 \%)$ by treated olive meal in part II by in vitro studies.

Statistical analysis: Statistical analysis was performed as per Snedecor and Cochran [10] and Duncan's multiple range test.

\section{Results and Discussion}

The proximate composition and fiber fractions of olive meal used in this study are shown in Table- 2 . 
Table-2. Chemical composition of olive meal

\begin{tabular}{lc}
\hline Attribute & $\begin{array}{c}\text { Percentage* } \\
\text { basis except } \text { moisture) }\end{array}$ \\
\hline Moisture & $8.63 \pm 0.07$ \\
OM & $95.94 \pm 1.12$ \\
CP & $7.61 \pm 0.16$ \\
EE & $9.11 \pm 0.12$ \\
CF & $41.22 \pm 0.83$ \\
TA & $2.42 \pm 0.05$ \\
AIA & $0.34 \pm 0.02$ \\
NFE & $38.09 \pm 0.61$ \\
NDF & $61.37 \pm 0.87$ \\
ADF & $52.34 \pm 1.16$ \\
Ca & $0.20 \pm 0.03$ \\
P & $0.16 \pm 0.02$ \\
\hline
\end{tabular}

Table-3. In vitro digestibility of composite diet comprising of maize replacement at $25 \%$ by olive meal treated with variable levels of lime

\begin{tabular}{lc}
\hline Percentage of lime (\%w/w) & IVDMD (\%) \\
\hline $0 \%$ (control) & $43.95^{\mathrm{a}} \pm 0.56$ \\
$2 \%$ & $45.00^{\mathrm{ab}} \pm 0.96$ \\
$3 \%$ & $45.70^{\mathrm{abc}} \pm 1.01$ \\
$4 \%$ & $46.53^{\mathrm{abc}} \pm 1.05$ \\
$5 \%$ & $47.15^{\mathrm{abc}} \pm 1.06$ \\
$6 \%$ & $48.33^{\mathrm{bc}} \pm 1.40$ \\
$7 \%$ & $48.58^{\mathrm{c}} \pm 1.18$ \\
$8 \%$ & $48.68^{\mathrm{c}} \pm 1.18$ \\
\hline
\end{tabular}

Means bearing different superscripts differ significantly $(P<0.05)$.

Table-4. In vitro dry matter digestibility of composite ration comprising of maize replacement by $6 \%$ lime treated olive meal on the in vitro digestibility of composite diet

\begin{tabular}{lc}
\hline Replacement level & IVDMD (\%) \\
\hline Replacement level -0\% (Maize-30\%, olive meal -0\%) & $51.83 \pm 1.33$ \\
Replacement level -25\% (Maize-22.5\%, olive meal -7.5\%) & $50.73 \pm 1.23$ \\
Replacement level -30\% (Maize-21\%, olive meal -9\%) & $50.40 \pm 1.96$ \\
Replacement level -35\% (Maize-19.5\%, olive meal -10.5\%) & $50.03 \pm 1.29$ \\
Replacement level -40\% (Maize-18\%, olive meal -12\%) & $50.13 \pm 1.38$ \\
Replacement level -45\% (Maize-16.5\%, olive meal -13.5\%) & $49.10 \pm 1.16$ \\
Replacement level -50\% (Maize-15\%, olive meal -15\%) & $48.53 \pm 1.01$ \\
\hline
\end{tabular}

Proximate composition of the olive meal used in this study was similar to those reported by previous reports of $[11,12]$. CP and CF content (\% dry matter (DM)) was in agreement to that provided by [13-15]. The per cent ether extract (EE) content was in agreement to the values of $[5,12,16]$. Chemical composition of olive meal has been shown to be influenced by factors such as geographical origin, procedure of production and processing $[17,18]$. Differences in terms of CP and EE content between some of the previous reports and results of this study for the olive meal may be attributed to difference in processing method as the olive meal available at Jammu is crude meal and was not subjected to solvent extraction, which explains the high EE\% of the analysed samples. The moisture content of olive meal in this study was considerably lower than the previous reports $[3,5,19]$ which may be due to the fact that olive meal available for this study was heaped outside the processing mill and was exposed to cold air and sunlight causing appreciable level of drying before the sample was collected. The NDF and ADF content of the olive meal were found to be 61.40 and 52.31 per cent, respectively on Full form of DMB (DMB). The values were similar to those recorded by $[4,7,13]$.

In vitro dry matter digestibility: Effect of variable concentration of lime used for treatment of olive cake on in vitro digestibility of composite diet is presented in Table-3. IVDMD of composite diet increased from $43.95 \%$ at $0 \%$ lime treatment to $48.68 \%$ on treating with $8 \%$ lime with significant $(P<0.05)$ increase at $6 \%$ treatment level. Lime treatment beyond $6 \%$ had no further significant effect on improving the digestibility. Treatment by $6 \%$ Lime was able to increase the IVDMD $\%$ by almost $10 \%$. The decrease in IVDMD at higher level of olive meal incorporation in diet has been attributed to various factors as; high concentrations of free fatty acids, presence of incriminating factors and high level of lignin with low cell contents. The lime treatment increases digestibility of fibrous feedstuffs is in agreement with [20]. It appears that improved digestibility with lime treatment may be due to the weakening of internal $\mathrm{H}$ bonding, thereby disrupting the fibre structure in olive cake and further lime may be saponifying the high level of fat present in olive cake, which may otherwise negatively impact the digestibility values. Level of lime above $6 \%$ was not able to further improve the IVDMD values. On the basis of results of trial I, $6 \%$ concentration of lime for olive meal treatment was selected and tested at variable level of maize replacement $(25 \%, 30 \%, 35 \%, 40 \%$, $45 \%$, and $50 \%$ ) by treated olive cake in trial II. Results of trial II are presented in Table-4.

The percent IVDMD of composite diet at all level of replacement tested was similar $(P>0.05)$ to the control diet. However, a point of inflection was observed at $45 \%$ replacement level. In trial II, the percentage IVDMD at various replacement level of maize by treated olive meal showed insignificant decline with increasing level, however, a small point of inflection was observed at $40 \%$ replacement level. The comparable IVDMD $(P>0.05)$ indicated that lime treatment was able to improve the IVDMD of the composite diet and therefore the sharp decline in IVDMD observed at levels higher than 25\% replacement in previous report [2] was not observed in the present study. Thus up to $40 \%$ replacement of maize by treated olive meal was suggested for incorporating in the diet of small ruminants [21,22]. The replacement levels higher than $40 \%$ would have made diet considerably low in readily available energy components and further because $40 \%$ level was showing a statistically insignificant inflection point. 


\section{Conclusions and recommendations}

Rising prices of conventional feedstuffs and their limited availability warrants use of unconventional feedstuffs. Olive (Olea europaea) meal is a promising unconventional feedstuff, which has potential to partially replace maize from the ration of ruminants. From the in vitro studies it may be concluded that:

* Treatment of olive meal with $6 \%$ lime (w/w) was able to alleviate digestibility depression caused by olive meal inclusion.

* Lime treated olive meal can partially replace maize from small ruminant ration. Incorporation of lime treated Olive meal as partial replacer of maize up to $40 \%$ shall be recommended for economic rearing of small ruminants that may be beneficial for livestock producers of the region.

\section{Authors' contribution}

All authors contributed equally. All authors read and approved the final manuscript.

\section{Acknowledgements}

The authors greatly acknowledge the Director of Research, SKUAST - Jammu, for his approval to carry out the experiment. Appreciation is expressed to technical staff of Division of Animal Nutrition, SKUAST - Jammu, for their help during the laboratory analysis.

\section{Competing interests}

Authors declare that they have no competing interest.

\section{References}

1. Grasser, L. A., Fadel, J. G., Garnett, I. and Depeters, E. (1995) Quantitative and economic importance of 9 selected byproducts used in California dairy rations. J. Dairy Sci. 78: 962-971.

2. Bashir, Y. (2011) Effect of dietary incorporation of Olive meal on the performance of goats. M.V.Sc. Thesis, SKUAST-J, Jammu, India.

3. Gharbi, F. R. and Benarif, T. (2011) Economical impacts of the use of olive cakes in animal nutrition in Tunisia. Biotechnologie, Agronomie, Société et Environnement, 15: 259-270.

4. Nefazoui, A. (1983) Etude de I'utilisation des sous-produits de I'olivier en alimentation animale en Tunisie. Anim. Prod. and Health Div. FAO, Rome.

5. Al-Jassim, R.A.M., Awadeh, F. T. and Abodabos, A. (1997) Supplementary feeding value of urea treated olive cake when fed to growing Awasi lambs. Anim. Feed Sci. Technol. 64: 287-292.

6. AOAC. (1995) Official Methods of Analysis, $16^{\text {th }}$ ed. Association of Official Analytical Chemists, Washington, DC, USA. Pp.:4.1-4.17.

7. Van Soest, P. J., Robetson, J. B. and Lewis, B. A. (1991). Methods for dietary fiber, and nonstarch polysaccharides in relation to animal nutrition. J. Dairy Sci. 74: 3538-3597.

8. Saadullah, M., Haque, M. and Dolberg, F. (1981) Lime treatment of paddy straw. Trop. Anim. Prod. 6: 116-119.

9. Tilley, J. M. A. and Terry, R. A. (1963). A two stage technidue for the in vitro digestion of forage crops. J. Br. Grassland Soc. 18: 104-111.

10. Snedecor, G. W. and Cochran, W. G. (1989). Statistical Methods. $7^{\text {th }}$ Edn. The Iowa State University, Iowa (USA).

11. Mioc, B., Pavic, V., Vnucec, I., Pripic, Z. and Susic, V. (2007) Effect of olive cake on daily gain, carcass characteristics and chemical composition of lamb meat. Czech J. Anim. Sci. 52(2): 31-36.

12. Sansoucy, R. (1985) Olive By-products for animal feed. FAO. Anim. Prod. and Health Paper 43, FAO, Rome.

13. Martin Garcia, A. I., Moumen, A. Yanez Ruiz D. and MolinaAlcaide, E. (2003) Chemical composition and nutrients availability for goats and sheep of two-stage olive cake and olive leaves. Anim. Feed Sci. Technol. 107: 61-74.

14. Hadjipanayiotou, M. (2000) The use of crude olive cake silage as small ruminant feed in Cyprus: a review. CahiresOptions Mediterraneennes, 52: 51-54.

15. Molina-Alcaide, E., Yanez Ruiz, D., Moumen, A. and Martin Garcia, I. (2003) Chemical composition and nitrogen availability of some olive byproducts. Small Rumin. Res. 49: 329-336.

16. Sadeghi, H., Teimori, A. and Ansari, Z. (2009) Effects of different olive cake byproducts on Dry Matter Intake, nutrient digestibility and performance of Zel sheep. Inter. $J$. Agri. Bio. 11:39-43.

17. Chiofalo, B., Liotta, L.,Zumbo, A. and Chiofalo, V. (2004) Administration of olive cake for ewe feeding: effect on milk yield and composition. Small Rumin. Res. 55: 169-176.

18. Rowghani, E., Zamiri, M. J. and Serdj, A. R. (2008) The chemical composition, rumen degradability in vitro gas production, energy content and digestibility of olive cake ensiled with additives. Iranian J. Vet. Res. 9: 213-221.

19. Al-Masri, M. R., (2003) An in vitro evaluation of some unconventional ruminant feeds in terms of the organic matter digestibility, energy and microbial biomass. Trop. Anim. Health and Prod. 35: 155-167.

20. Salvendra, S. A., Matsonka, S. And Fujita, H. (1981) Studies on improvement in the feeding value of rice straw. Res. Bulletin Obihiro University, Japan, 10: 447-459.

21. Jamal M. A. O., Raed D. and Ghaleb A. (2012) Effects of different forms of olive cake on the performance and carcass quality of Awassi lambs, Anim. Feed Sci. Technol. 171: 167172.

22. Molina-Alcaide, E. and Yanez Ruiz, D. (2008) Potential use of olive by-products in ruminants. Small Rumin. Res. 11:37-39. 